\title{
A tolerância segundo o amor de Voltaire
}

\author{
Jackson Chediak \\ Sorhaya Chediak
}

\section{Considerações iniciais}

\begin{abstract}
A retórica enquanto ciência nos permite compreender a linguagem e o modo como nos comunicamos. Podemos persuadir um auditório por meio do discurso verbal ou não verbal ao empregarmos elementos persuasivos que podem levá-lo à comoção. Neste contexto, é relevante considerar quem argumenta, o que argumenta, como argumenta e para quem argumenta, visto que podemos criar efeitos de sentido para o público a quem a argumentação está direcionada. Isto acontece porque a persuasão está relacionada ao modo como usamos a razão ou a emoção. Neste contexto, consideramos também o caráter do orador, a maneira que ele se projeta para o auditório formando os três tipos de argumentos: ethos, pathos e logos.

A partir destes princípios, propomos para este estudo analisar a retórica de Voltaire pela tolerância, com base na obra "Tratado sobre a tolerância" em comparação com a "Carta sobre tolerância", de John Locke. Além disso, consideramos os elementos empregados na argumentação por Voltaire e como ele legitima a tolerância a partir de um fato histórico envolvendo católicos e protestantes, bem com as imposições políticas, morais e religiosas segundo o amor de Voltaire.

De acordo com Ferreira, "agimos retoricamente quando valemos do discurso para descrever, explicar e justificar nossa opinião com objetivo de levar o outro a aceitar nossa posição". ${ }^{1}$ Partindo disso, somos levados ao seguinte questionamento: Como a retórica contribui para a compreensão do discurso persuasivo?
\end{abstract}

$1 \quad$ Ferreira, 2017, p. 13 
Assim, empregamos os estudos teóricos sobre a análise retórica que consideram elementos como: gênero retórico, provas retóricas, argumentação, características da argumentação e técnicas argumentativas, para analisar os textos. Procuramos identificar como o mecanismo de seletividade e formação do estereótipo do inimigo, na retórica dos violentos, são utilizados na obra de Voltaire e Locke como construção teórica do amor pela tolerância; bem como comparar as obras desses autores.

Como caminho metodológico optamos por uma pesquisa de abordagem qualitativa, buscando analisar os fenômenos sociais, como discursos da tolerância são abordados nas obras, com base na pesquisa bibliográfica.

Consideramos os estudos de Ferreira (2017) sobre retórica e persuasão, os de Mateus (2018) em relação ao pathos, Tringali (2014) no que se refere ao estudo das provas intrínsecas, de Campbell, Huxman e Burckholder (2015) sobre as evidências empregadas para persuadir o auditório e os conhecimentos de Reboul (2004) e Fiorin (2020) sobre a argumentação. Como resultado da nossa análise, foi possível identificar o amor de Voltaire pela tolerância, bem como o discurso dos violentos respaldado em uma falsa premissa cristã.

Inicialmente, apresentamos o conceito sobre retórica e a contextualização da obra "Tratado sobre a tolerância". Em seguida, discorreremos sobre o gênero judiciário, os elementos argumentativos e a retórica da tolerância em Voltaire. A partir desse último, faremos a análise e discussão dos dados. Por fim, buscamos estabelecer uma interlocução entre Voltaire e Locke, a fim de analisar como eles constroem seus argumentos em relação à tolerância. Nas considerações finais traçamos algumas reflexões sobre o amor de Voltaire pela tolerância.

\section{Retórica: breves conceitos}

A retórica é uma ferramenta importante na comunicação, pois por meio dela podemos elaborar o discurso de maneira a persuadir o auditório. De acordo com Ferreira, "(...) somos seres retóricos por termos crenças, valores e opiniões, valemo-nos da palavra como instrumento revelador de nossas impressões sobre o mundo, de nossos sentimentos, convicções dúvidas, paixões e aspirações". $\mathrm{Ou}$ seja, nossos discursos são produzidos a partir do lugar que ocupamos em um determinado contexto social, das nossas memórias, vivências e experiências.

A palavra tem uma carga semântica que pode construir ou desconstruir uma ideia, uma opinião. Ao produzirmos nosso discurso podemos despertar paixão

2 Ferreira, 2017, p. 12 
(pathos) e conquistar o auditório ou fazer com que sejamos mal vistos, pois “(...) todo discurso é uma construção retórica, uma vez que procura conduzir o auditório numa direção determinada e projetar pontos de vista em busca de adesão (...)".3

É possível aplicar a retórica na vida e nas relações sociais como um todo. Ela promove mais clareza na comunicação e, consequentemente, nos relacionamentos, o que ocorre não só para o falante (orador) que elabora o discurso para persuadir, mas também para os ouvintes (auditório), uma vez que a compreensão da retórica permite ao orador e auditório "desvendar os discursos".

De acordo com Reboul, “(...) a 'retórica' assumiu sentidos bem diversos e até divergentes". ${ }^{4}$ A fim de buscarmos esclarecimento quanto à conceituação de retórica, apresentamos na sequência um quadro com os conceitos sobre retórica, formulados por alguns estudiosos.

Quadro 1: Conceitos de Retórica

\begin{tabular}{|l|l|}
\hline Ferreira (2017, p. 46) & $\begin{array}{l}\text { "A retórica contemporânea veio cheio de saúde: não pretende, } \\
\text { especificamente, ensinar a produzir textos, mas, sobretudo, } \\
\text { objetiva oferecer caminhos para interpretar os discursos." }\end{array}$ \\
\hline $\begin{array}{l}\text { Mateus (2018, p. } \\
\text { 23-24) }\end{array}$ & $\begin{array}{l}\text { "(...) a Retórica é um campo de possibilidades. (...) A Retórica é, } \\
\text { desse modo, o espaço da resposta múltipla e o lugar por excelência } \\
\text { da argumentação." }\end{array}$ \\
\hline Tringali (2014, p. 21) & $\begin{array}{l}\text { "(...) a Retórica Antiga admite duas linhas de definição em } \\
\text { choque: a primeira concebe a Retórica como arte de dizer bem, } \\
\text { dizer adequadamente da melhor forma possível seja o que for e a } \\
\text { segunda concebe a Retórica como arte de persuadir um auditório, } \\
\text { por meio de provas." }\end{array}$ \\
\hline $\begin{array}{l}\text { Campbell, Huxman } \\
\text { e Burckholder (2015, } \\
\text { p. 9) }\end{array}$ & $\begin{array}{l}\text { "Retórica é o estudo do que é persuasivo." } \\
\text { "Retórica é o uso pleno de propósito de mensagem para convidar à } \\
\text { provocação." } \\
\text { "Retórica é a técnica de produzir discurso justificado que é } \\
\text { fundado em verdades sociais." }\end{array}$ \\
\hline $\begin{array}{l}\text { Reboul (2004, p. } \\
\text { XIV) }\end{array}$ & "(..) retórica é a arte de persuadir pelo discurso." \\
\hline Fiorin (2020, p. 19) & "A retórica é a arte da persuasão, a 'arte do discurso eficaz". \\
\hline
\end{tabular}

Fonte: elaborado pelos autores, 2020.

3 Ibid., p. 49

4 Reboul, 2004, p. XII 
Dessa maneira, a partir dessas conceituações, podemos afirmar que a Retórica oferece elementos para a compreensão dos discursos e refere-se tanto à arte da persuasão, quanto à arte de falar bem, ou seja, de maneira efetiva. A maior parte dos autores mencionados no quadro acima, no entanto, concordam que a Retórica está ligada à arte da persuasão, ao discurso justificado e fundamentado.

A Retórica fornece os caminhos para a compreensão de como o discurso se estrutura internamente, seus mecanismos e técnicas. Com efeito, ter consciência sobre a retórica e de como ela ocorre nas interações sociais, nos textos e no cotidiano em geral, pode contribuir para a compreensão das estratégias discursivas, para a elaboração dos argumentos de maneira persuasiva, e para a interpretação dos discursos.

As análises e reflexões desses autores contribuem com a elucidação de conceitos sobre a retórica, proporcionam suporte e compreensão da "artimanha do dizer." Elementos como: quem fala, o que se fala, como se fala, de qual lugar se fala precisam ser considerados ao analisar e/ou elaborar um texto, tendo em vista que demonstram a intencionalidade do orador e a forma como ele pode elaborar seu discurso. Para tanto, trataremos da obra "Tratado sobre a tolerância", de Voltaire, a fim de contextualizar o leitor em relação à proposta do nosso estudo.

\section{Tratado sobre a tolerância de Voltaire e a Carta sobre a tolerância de Locke}

A obra "Tratado sobre a Tolerância" de Voltaire aborda o fanatismo religioso e defende a tolerância por meio da emoção provocada no auditório com a imersão em um caso concreto, ocorrido na província de Toulouse, França, que era, predominantemente, católica. No subtítulo da obra, "por ocasião da morte de Jean Calas", há um desdobramento acerca do tema principal e, ao mesmo tempo, direciona o olhar do auditório para um dos maiores erros em julgamentos ocorridos na França do século XVII.

As circunstâncias históricas em que a obra se situa estão ligadas ao contexto de conflitos religiosos. É sob a perspectiva do cristianismo que Voltaire evoca a Bíblia para descrever a intolerância mútua entre cristãos. O filósofo retrata os erros e os abusos cometidos historicamente em razão dos dogmas. Voltaire afirma que "os japoneses eram os mais tolerantes de todos os homens; doze religiões pacíficas estavam estabelecidas em seu império.". Assim, o autor reforça a ideia

$\overline{5}$ Voltaire, 2017, p. 34 
de que é possível conviver pacificamente com as diversas religiões quando há tolerância religiosa.

Voltaire narra em sua obra a história de Jean Calas, um senhor de 68 anos, protestante, comerciante, casado e pai de família, em uma província da França, Toulouse, do século XVII, permeada pela intolerância religiosa. O idoso foi acusado injustamente de enforcar o próprio filho, Marco Antônio, por este ter se convertido ao catolicismo. Condenado por crime de parricídio, Jean Calas foi morto na Roda do Suplício.

Marco Antônio era um homem letrado, descrito como "espírito inquieto e violento”. Apesar de sua educação, ele não conseguiu seguir nenhuma carreira e nem mesmo ser aprovado como advogado porque era necessário ter certificado de catolicidade que não pode obter por ser de uma família de protestantes. Essa foi possivelmente a maior motivação do atentado contra sua própria vida, tendo em vista que comentou sobre seu plano com o amigo Lavaisse. Sem entender o real contexto e movido por falsas hipóteses, um fanático religioso aclamou pela condenação do pai de Marco e obteve reforço público, acreditando que este o teria matado por ter se tornado católico.

O caso é descrito como “(...) uma precatória não menos viciosa que os procedimentos". ${ }^{\circ}$ Os argumentos do orador são fundados nas minúcias apresentadas pelos advogados de Toulouse. Quando Voltaire (2017) menciona esses detalhes, ele esclarece que não eram suficientes para justificar a condenação de Jean Calas.

Outra obra que nos propomos a tratar neste artigo é a "Carta sobre a tolerância” de John Locke, escrita no ano de 1683, na Holanda, quando ele estava refugiado em exílio. A carta inicia com "honorável senhor" o que demonstra um direcionamento para pessoa específica que, neste caso, era Phillip van Limborch.

A escrita, ao contrário do Tratado de Voltaire, não foi direcionada a uma infinidade de leitores ou pessoas, mas a uma pessoa com quem trocou correspondências. A carta versou sobre a tolerância por meio da separação entre poderes e incumbências do Estado, da comunidade e da igreja, pois, para autor, enquanto houvesse a confusão no papel de cada um, não haveria tolerância ou progresso na busca por ela.

Entre os argumentos que fundamentam a separação entre Estado e Igreja, há o direcionamento de opinião quando se Locke se refere aos magistrados: "Por fim, considerando qual o dever do magistrado com respeito à tolerância, que por certo é bem considerável. Já provamos que cuidado das almas não é a 
província do magistrado."7 É possível perceber que o orador faz críticas aos magistrados que não desassociam a fé de seus deveres.

A carta de Locke não se trata de um caso concreto específico de intolerância religiosa. Ela registra a opinião do autor quanto à separação de assuntos civis das convicções religiosas ou mesmo da religião, em especial a magistratura. Para o filósofo, "A magistratura não obriga a pôr de lado a humanidade ou o cristianismo, mas uma coisa é persuadir e outra ordenar, assim como uma coisa é conduzir por meio de argumentos e outra fazê-lo por meio de punições." ${ }^{\text {E }}$ possível observar que o autor separa credo particular de decisões judiciais, por acreditar que o primeiro pode influenciar e estimular perseguições àqueles que não comungam do mesmo fundamento religioso. Assim, o filósofo evidencia que as pessoas que praticavam perseguições religiosas justificam as ações nos princípios cristãos, a fim de legitimar as barbáries cometidas contra àqueles que discordam em questões religiosas.

A seguir, discutiremos a respeito do gênero oratório judiciário a partir da obra de Voltaire, tendo em vista que este trata da defesa de uma argumentação com finalidade de esclarecer fatos e tem como auditório os juízes que acusam ou defendem uma ideia.

\section{O gênero judiciário e os elementos argumentativos na condenação de Jean Calas}

Ao desconstruir as alegações que levaram à condenação de Jean Calas, Voltaire aborda as evidências apresentadas e arguidas para justificá-las. Em seus argumentos, demonstra que tais evidências não guardam proximidades com o valor de justiça, fazendo com que o auditório, como "gênero humano", examine se a religião "deve ser caridosa ou bárbara".

Entre os questionamentos apresentados, o autor, por meio de figuras retóricas, questiona as inconsistências do discurso acusatório acerca da culpabilidade de Calas:

Parecia impossível que Jean Calas, de sessenta e oito anos de idade, que havia muito tempo tinha pernas inchadas e fracas tivesse estrangulado sozinho e enforcado um filho de vinte oito anos, que tinha 
uma força acima do normal. Era absolutamente necessário que tivesse sido auxiliado nessa execução por sua mulher, por seu filho Pedro Calas, por Lavaise e pela criada muda. Não se haviam deixado um só momento na noite dessa desgraça fatal. Mas essa suposição era ainda mais absurda que a outra, pois, como uma criada católica convicta poderia ter tolerado que huguenotes assassinaram um jovem que ela havia criado para puni-lo por gostar da religião dessa criada?"10

Voltaire (2017), com propósito retórico de desconstruir a tese acusatória, cria efeitos de presença com frases interrogativas que levam o auditório à resposta esperada ou projetada em seus argumentos ad populum, “(...) os quais visam razões que justificam ou refutam um determinado ponto de vista", ${ }^{11}$ por meio da emoção do auditório.

É possível perceber que o autor cria argumentos direcionados para um público específico capaz de anular a sentença, ou seja, a retórica é orientada a quem competia retomar o curso da ação, bem como apreciar provas documentadas no julgamento. No entanto, desperta a emoção para provocar clamor em parte do auditório alheio à técnica forense.

De acordo com Mateus (2018), a diferenciação dos tipos de gêneros retóricos é didática. Contudo, quando o orador organiza seus argumentos a partir de um o gênero retórico, ele define recursos, finalidades e valores que contribuem para a sustentação do discurso. Ou seja, “(...) cada gênero é determinado com diferentes critérios: o auditório a que se dirige, a finalidade do que produz, o tempo a que se refere e os valores que rege". ${ }^{2}$

O gênero judiciário compreende características e técnicas empregadas na argumentação e sua organização é direcionada a um público específico. O orador acusa ou defende uma tese e tem como auditório os juízes. A argumentação está fundamentada na concepção de valores como justo/injusto e relaciona-se ao passado. Reboul (2004) aponta questões importantes sobre o gênero judiciário.

O judiciário refere-se ao passado, pois são fatos passados que cumpre esclarecer, qualificar, julgar.

(...)

10 Ibid., p. 18, grifo nosso

11 Fiorin, 2020, p. 223

12 Mateus, 2018, p. 97 
O judiciário, que dispõe de leis e se dirige a um auditório especializado, utiliza de preferência raciocínio silogísticos (entimemas), próprios a esclarecer a causa dos atos. ${ }^{13}$

A retórica do tratado sobre a tolerância emprega argumentos de desconstrução de uma sentença que levou ao suplício um protestante acusado de matar o filho católico, em um processo de ruptura com a polaridade religiosa da época, ou cenário da condenação. $\mathrm{O}$ auditório é levado a examinar o que pregava a religião e construir a partir da caridade, o amor pela tolerância.

Por meio de comparações e passagens bíblicas, o autor cria exemplos capazes de inserir o auditório no evento, como se ele participasse da cena com sensações de angústia, tristeza e indignação. Outro recurso empregado é a ironia, como podemos perceber quando afirma: “(...) Uma devota, um tanto surda, disse que havia ouvido o toque dos sinos. (...) Eram redigidas atas desses prodígios." ${ }^{14}$ A ironia com que o orador descreve a canonização de Marco Antônio, filho de Jean Calas, tem forte efeito argumentativo porque desvaloriza as ações da população e orienta o auditório a refletir a ação.

Podemos notar o emprego de estratégias retóricas que promovem a possibilidade de o leitor elaborar imagens de uma cena, quando o autor descreve uma devota que, embora seja um tanta surda, ouve o soar dos sinos. Neste contexto, Campbell, Huxman e Burkholder afirma que “(...) a força retórica de um exemplo reside na sua capacidade de promover visualização: fazer com que imaginemos uma cena, que participemos dela, que nos identifiquemos com pessoas e eventos". ${ }^{15}$ Desta maneira, podemos afirmar que as estratégias retóricas empregadas por Voltaire são fortes o suficiente para o leitor criar uma imagem e quase testemunhar a leviandade de uma intolerante religiosa.

O orador coloca o auditório na condição de juiz para rever o julgamento, mediante a apresentação e a verificação da ocorrência dos fatos. Neste sentido, Voltaire afirma que "A religião foi instituída para nos tornar felizes nesta vida e na outra. Que é preciso fazer para ser feliz na vida futura? Ser justo." ${ }^{6}$ Observa-se que o orador buscou na racionalidade uma maneira de persuadir o auditório e, assim, argumentar com base no que ele pensa ser justo e correto em relação à sentença.

No próximo tópico, discutiremos sobre o amor de Voltaire pela retórica da tolerância, analisando os elementos empregados na construção do discurso.

13 Reboul, 2004, 45-46

14 Voltaire, 2017, p. 16

15 Campbell; Huxman; Burkholder, 2015, p. 68

16 Voltaire, 2017, p. 123 
Para tanto, partimos do entendimento de que há diversas formas de elaborar o texto que podem contribuir de maneira significativa para a intenção do orador em persuadir o auditório.

\section{O amor de Voltaire e a retórica da tolerância}

Voltaire, na política se opôs ao antigo regime ${ }^{17}$ que concentrava os poderes executivo, legislativo e judiciário nas mãos do monarca, facilitando a arbitrariedade. $\mathrm{O}$ filósofo empirista tece duras críticas às decisões autoritárias dos governantes que, de acordo com o mesmo, deveriam governar segundo as leis.

Para abordar o amor em Voltaire é necessário compreender que ele defendia a liberdade e os ideais iluministas que se resumem na tolerância. ${ }^{18} \mathrm{O}$ amor de Voltaire pela tolerância se relaciona às ideias que colocam a razão como penhor, em combate a um fanatismo religioso que dominou a Europa do século XV até o início do século XIX. Para o filósofo, o respeito às leis e submissão da igreja às normas do Estado proporcionariam uma tolerância social.

Ao relatar o propósito da morte de Jean Calas no tratado sobre a tolerância, publicado em 1763, Voltaire mostra uma religião que deixava de lado a caridade para praticar injustiças, que ao invés de promover o amor, promovia o ódio e a perseguição. Isso pode ser percebido na passagem "Essa cidade celebra ainda todos os anos, com uma procissão e com fogos, o dia em que massacrou quatro mil hereges, há dois séculos". ${ }^{19}$ Neste contexto, Mateus evidencia a importância do orador na mobilização de sentimentos e percepções do auditório.

Um orador competente mobiliza as crenças, sentimentos, percepções e simpatias do auditório para, desse modo, interferir no processo de persuasão. O pathos é composto pelo conjunto de emoções, paixões e sentimentos que o orador pode suscitar no auditório por intermédio do seu discurso. ${ }^{20}$

Voltaire apostava na razão como promoção da paz, amor e tolerância. Em sua obra, o filósofo desperta na população francesa emoções e sentimento de piedade, ao inserir provas intrínsecas fundamentadas em passagens bíblicas e na morte de Jean Calas, para defender a tolerância.

17 Monarquia absolutista

18 No sentido de ter disposição para aceitar e/ou admitir modos de pensar, com base em uma razão

19 Voltaire, 2017 , p. 15

20 Mateus, 2018, p. 109-110 
Além disso, para sustentar os argumentos, ele recorre às palavras e expressões como: injustiça, violência, desatino, fanatismo, suplício, abuso da religião, crime, dogma monstruoso, a fim de descrever os juízes de Toulouse que fizeram a acusação a Calas, e comover o auditório.

Ao empregar as figuras de escolha para qualificar a atitude dos os juízes de Toulouse, “(...) o orador, por meio da linguagem figurada (...) encontra uma maneira de qualificá-lo, caracterizá-lo e interpretá-lo, de acordo com seu interesse argumentativo". ${ }^{21}$ Deste modo, Voltaire evidencia seu posicionamento e constrói, por meio do universo da doxa, ou seja, mundo das opiniões, seus argumentos em relação a atitude que condenou um pai inocente.

Ou os juízes de Toulouse, influenciados pelo fanatismo da multidão, condenaram ao suplício da roda um pai de família inocente, o que é inédito; ou esse pai de família e sua mulher estrangularam seu filho mais velho, auxiliados no crime por outro filho e por um amigo, o que não é conforme à natureza. Num e noutro caso, o abuso da mais santa religião produziu um grande crime. É, portanto, do interesse do gênero humano examinar se a religião deve ser caridosa ou bárbara. ${ }^{22}$

Enquanto os juízes de Toulouse são descritos com palavras que evocam a injustiça, os advogados que defendiam a família Calas são exaltados por meio das palavras como sensatos, sensíveis, generosos, defensores das leis e da inocência. O filósofo recorre aos valores para alcançar a aprovação do auditório.

O senhor de Beaumont, célebre advogado do parlamento de Paris, tomou primeiramente sua defesa e redigiu um auto de defesa que foi assinado por quinze advogados. O senhor Loiseau, não menos eloquente, compôs um memorando em favor da família. O senhor Mariette, advogado no conselho, redigiu uma petição jurídica que convencia todos os espíritos.

Esses três generosos defensores das leis e da inocência entregaram para a viúva o lucro das publicações impressas de seus discursos de defesa. ${ }^{23}$

Os valores são construídos socialmente e estão relacionados à sociedade e ao que ela considera como verdade em uma determinada época. "Um orador competente mobiliza crenças, sentimento, percepções e simpatias do auditório

21 Ferreira, 2017, p. 128

22 Voltaire, 2017, p. 21

23 Ibid., p. 20 
para, desse modo, interferir no processo de persuasão." ${ }^{24}$ Ao mesmo tempo em que as palavras desqualificam as atitudes dos juízes, elas também reforçam a imagem negativa e contribuem para que o auditório avalie a decisão que matou um homem inocente.

A postura impositiva dos juízes, vista como intolerante, e a dos advogados de defesa, descritos como generosos, são estratégias simbólicas que Voltaire recorre para abordar o assunto. Segundo Fiorin, "argumentar é apresentar razões que justificam ou refutam um determinado ponto de vista". ${ }^{25}$

É possível perceber que o orador empregou estratégias distintas para argumentar e persuadir de maneira formal e convincente "Rogo a todo leitor imparcial para que pese essas verdades, as ratifique e as difunda. Leitores atentos, que comunicam entre si suas ideias, sempre vão mais longe que o autor" ${ }^{26} \mathrm{O}$ autor destaca a importância do leitor imparcial e atento à leitura. No entanto, compreendemos que nesta passagem também há emprego de estratégia retórica, visto que, ao mesmo tempo em que coloca a imparcialidade na leitura como uma virtude, utiliza em seu texto diversas técnicas argumentativas para persuadir o leitor de suas ideias.

O discurso somado aos apelos emotivos desperta o respeito de seu auditório que é mencionado como imparcial e atento, convidado a repensar a sentença. Esse tipo de discurso se vale de valores existentes na sociedade que envolvem não só os aspectos sociais como punição de quem mata, mas também os aspectos pessoais, ligados às emoções.

O auditório está diante de um caso narrado pela versão do orador que apresenta uma perspectiva na qual a religião e o clamor do povo são mostrados como causadores da condenação de Jean Calas: “Treze juízes se reuniram todos os dias para terminar o processo. Não havia nenhuma prova contra a família, mas a religião enganada servia de prova" ${ }^{27}$ Agora o auditório, "atento e imparcial", pode rever o caso da condenação, já que estão mais abertos para concordarem com os argumentos de Voltaire.

Dessa forma, o autor mobiliza os valores do auditório na tentativa de organizar a hierarquia dos lugares e estabelecer a adesão por meio do acordo prévio sobre o preferível que é “(...) constituído por valores, hierarquia de valores e lugares. (...) Na Retórica, são os valores morais que mais importam já que tendem a determinar o conjunto de regras pelas quais os seres humanos coexistem 
na sociedade." ${ }^{28}$ Os valores estão presente desde o início da argumentação, descritos nas ações dos juízes de Toulouse, na família de Calas, no conselho do rei, e no tribunal.

A sentença de Jean Calas não foi proferida de acordo com as leis e com equidade. Os acontecimentos narrados apontam que os magistrados sentenciaram à morte um homem inocente devido à intolerância religiosa e à pressão da população, por ocuparem um lugar de superioridade na hierarquia do poder. Com este argumento, Voltaire consegue envolver o auditório, despertando paixões e amplificando a retórica da tolerância.

Ao organizar o texto, o orador elabora a argumentação com escolhas de palavras que constroem uma imagem positiva de Jean Calas como "pai de família", "pai inocente", "homem virtuoso", "bom pai", "inocente" e "vítima de uma província bárbara e fanática”. Por outro lado, Voltaire descreve o julgamento dos juízes de Toulouse à família calas como "violento", “abusivo" e "bárbaro".

Para Voltaire, "o direito da intolerância é, portanto, absurdo e bárbaro; é o direito dos tigres, e realmente horrível, porque os tigres não dilaceram senão para comer, enquanto nós nos dilaceramos por causa de alguns parágrafos". ${ }^{29}$ Com essa construção argumentativa, o autor reforça sua reprovação em relação às atitudes e aos julgamentos pautados na inclemência ao empregar adjetivos para caracterizar a intolerância como uma atitude violenta.

Ao fazer a comparação entre o comportamento dos tigres e o dos homens, o autor evidencia que o "direito da intolerância" não é justificado. A expressão: "os tigres não dilaceram senão para comer ${ }^{30 "}$ demonstra o emprego do lugar da qualidade, para sustentar a sua argumentação no discurso dele para o auditório.

Os argumentos por comparações e exemplos podem ser percebidos durante todo o texto, como na passagem: "Finalmente, essa tolerância nunca cobriu a terra de carnificinas. Que se julgue agora entre essas duas rivais, entre a mãe que quer que o filho seja degolado e a mãe que o cede, contanto que viva." ${ }^{31}$ Ao tratar da tolerância e da intolerância religiosa no julgamento de Calas, o orador apela à comoção do auditório.

Para o autor, o “(...) escrito sobre a tolerância é uma petição que a humanidade apresenta humildemente ao poder e à prudência. Semeio um grão que poderá um dia produzir uma colheita". ${ }^{22}$ A intolerância é descrita como abusiva, 
perversa, perseguidora e gera hipocrisia, enquanto que a tolerância é descrita como benevolente, virtuosa, generosa, justa.

A seguir apresentamos os diálogos entre Voltaire e Locke, e como esses filósofos constroem a retórica do amor pela tolerância.

\section{Diálogos sobre tolerância em Voltaire e John Locke}

O caso emblemático escrito por Voltaire (2017) leva o auditório a agir como juízes. Conforme Ferreira, “(...) aqueles que analisam uma causa passada ponderam sobre o justo, o legal e sobre o injusto, o ilegal, consideram a ética envolvida e, a partir da reflexão, condenam ou absolvem". ${ }^{33}$ Dessa forma, os questionamentos apontados pelo filósofo despertam comoções e apelam para a tolerância entre os homens.

Não é necessária de uma grande arte, uma eloquência muito rebuscada para provar que os cristãos devem tolerar-se uns aos outros. Vou mais longe, afirmo que é preciso considerar todos os homens como nossos irmãos. O que? O turco meu irmão? O chinês meu irmão? O judeu? O habitante do Sri Lanka? Sim, sem dúvida. Não somos todos filhos do mesmo pai e criaturas do mesmo Deus? ${ }^{34}$

As indagações contribuem com o efeito argumentativo e evidenciam a intenção do orador que questiona a condenação. Desta maneira, ele propõe a tolerância em um contexto de injustiça e expressa seu desejo de anulação da sentença considerada bárbara.

Voltaire concluiu que a morte do comerciante Jean Calas, por meio de tortura física, na roda, ${ }^{35}$ decorreu de uma fé que contrariava uma França predominantemente católica ou mesmo de um fanatismo religioso que discordava das liberdades civis, bem como da corrupção na condução de processos, a depender da influência da pessoa julgada ou jurisdicionada.

Os argumentos de Voltaire encontram razões na influência de John Locke, apesar do autor abordar a tolerância em um tratado a partir de um caso concreto, em que desconstrói o que pregava a religião, não propôs a separação entre

33 Ferreira, 2017, p. 22

34 Ibid., p. 125

35 A roda de despedaçamento, ou roda de Santa Catarina, foi um instrumento de tortura destinado a execução pública de pessoas condenadas a penas capitais, desde a antiguidade clássica até o início da modernidade, onde tinham os ossos quebrados 
Estado e igreja. A tolerância religiosa de Voltaire é deísta com base na razão e na existência de Deus.

Não é mais, portanto aos homens que me dirijo; é a ti, Deus de todos os seres, de todos os mundos e de todos os tempos.

(...) Que todos os homens possam recordar que são irmãos! Que tenham verdadeiro horror da tirania exercida nas almas, como têm como execrável o banditismo que destrói pela força o fruto do trabalho e da indústria pacífica! Se os flagelos da guerra são inevitáveis, não nos odiemos, não nos dilaceremos uns aos outros no seio da paz e empreguemos o instante de nossa existência em abençoar igualmente em mil línguas diversas, desde o Sião até a Califórnia, tua bondade que nos deu este instante. ${ }^{36}$

Todo o discurso de Voltaire está respaldado na tolerância entre os homens, independente da religião. O filósofo exemplifica com passagens do Evangelho que Jesus Cristo pregou o amor ao próximo, a paciência e a misericórdia. Nesse contexto, é possível perceber que o orador construiu o discurso por meio de provas intrínsecas indutivas.

De acordo com Tringali, "As provas intrínsecas são totalmente preestabelecidas pela Retórica e aplicadas pelo orador. Elas ocorrem no desenvolvimento do assunto." ${ }^{37}$ Ao exemplificar com passagens bíblicas e analogias entre a tolerância e a intolerância religiosa em diferentes povos, o orador induz o auditório a refletir que "amar ao próximo" independe da religião.

$\mathrm{Na}$ "Carta sobre a tolerância", de John Locke, a tolerância está vinculada a separação entre a religião e o Estado. O autor apoia-se na importância da divisão entre os poderes do Estado e igreja, por ocuparem campos distintos na política. Inicia seus argumentos defendendo que a religião cristã deve ser tolerante, conforme podemos observar:

Considerando ser de vosso agrado perguntar minha opinião acerca da tolerância mútua entre cristãos em suas diferentes confissões religiosas, devo responder, com brevidade, que considero a tolerância a principal marca distintiva da verdadeira Igreja. ${ }^{38}$ 
O orador sustenta que a tolerância diante da diversidade da fé cristã deve necessariamente ser uma marca do que ele considera a verdadeira Igreja. Ele define o que é ser um cristão, atribuindo características incompatíveis com a intolerância: "A crer no Evangelho e nos apóstolos, ninguém pode ser cristão sem caridade, e sem aquela fé que age, não pela força, mas pelo amor". ${ }^{39}$

O filósofo descreve o cristão como sendo uma pessoa caridosa, branda, de espírito puro na conduta, que tenha boa vontade com o próximo, mesmo que este não seja cristão, ou professe fé distinta. Entre as características atribuídas por Locke a um cristão, está o amor. Assim, perseguições e violência a um semelhante e/ou infiel não se justificam, por contrariar a definição do que é um cristão, bem como por ser inoportuna a propagação do cristianismo por um não cristão.

A contra-argumentação de Locke pauta-se na desconstrução da ideia de justificar a violência para converter outros cristãos como se fosse uma caridade, tudo em nome da salvação dos infiéis.

Diante disso, apelo à consciência dos que perseguem, atormentam, destroem e matam outros homens sob o pretexto da religião: acaso o fazem por amizade e bondade? (...) Porque, se é por caridade, como alegam, e amor pelas almas humanas, que as despojam de suas propriedades, mutilam com castigos corporais, deixam famintos e atormentam em prisões infectas e no final até lhes tiram a vida. ${ }^{40}$

Com isso, o autor expõe as bases frágeis nas quais os argumentos sobre a caridade e a busca da salvação de não fiéis estão postos, os quais buscam justificar atos violentos e intolerantes em nome dessa salvação, o que se constitui como um falso interesse cristão em que “(...) homens empenhando-se em alcançar o poder e o domínio uns sobre os outros do que da igreja de Cristo”. ${ }^{41}$ Nenhuma religião poderia ser imposta ao homem e, por isso a igreja seria o lugar em que todos se reúnem voluntariamente.

Não se pode negar a nenhum homem não o cuidado magistrático (se assim se pode dizer), ou seja, aquele que consiste em prescrever por meio de leis e compelir mediante punições, mas sim o cuidado caridoso, que consiste em ensinar, admoestar e persuadir. Por conseguinte,

\footnotetext{
39 Ibid., p. 6

40 Ibid., p. 6

41 Locke, 2019, p. 5
} 
o cuidado da alma de cada homem pertence a ele próprio e deve ser deixado a seu cargo. ${ }^{42}$

Ao propor uma separação da política e religião, Locke questiona às suas próprias ideias. No debate sobre a isenção que os juízes devem ter das convicções religiosas, ele realiza interpelações seguidas. Esse recurso esgota as possibilidades de fragilização dos argumentos e refutações, direcionando o auditório às suas reflexões.

Voltaire e Locke se aproximam em diversos aspectos ao fundamentar o discurso em valores como justo/injusto, tolerante/intolerante. Ainda mais, ambos citam passagens bíblicas, as quais autorizam o discurso, em exemplos de intolerância religiosas, nos valores que demonstram a intencionalidade com argumentos que sustentam a ideia do modelo de virtude da tolerância religiosa e a ideia de que a fé de uma pessoa não pode ser imposta, ou ainda, servir de motivo para praticar iniquidades.

Enquanto Voltaire escreveu para um auditório especializado, com intenção de publicar e persuadir a revisão da condenação de Jean Calas, Locke escreveu para um auditório particular, a quem a carta é destinada, com o objetivo de justificar a sua convicção da necessidade da separação dos poderes do Estado e igreja. Para o filósofo, a religião e a política deveriam desempenhar papéis distintos.

A tolerância de Voltaire procura desencorajar ou mesmo reformar uma decisão em um caso concreto, mediante discurso do gênero judiciário, com análise de valores e apreciação de provas, na busca de influenciar o livre convencimento de juízes; enquanto que na tolerância de Locke, as indagações e as respostas aos próprios questionamentos refutam as possibilidades de possíveis indagações, sem a apreciação de um caso particular, mas em uma análise genérica. Percebe-se que o autor argumenta e contra-argumenta para um auditório específico, uma maneira de antecipar as possíveis teses contrárias aos seus argumentos e, com isso, alcançar a verossimilhança de seu auditório.

\section{Considerações finais}

Conhecer a retórica é ter a oportunidade de ampliar a análise/compreensão dos discursos nas suas diversas formas, verbal, textual, verbo-visual, simbólico e, a partir disso, desenvolver a criticidade, tanto a respeito de valores, lugares

42 Ibid., p. 25-26 
comuns, estereótipo, crenças, quanto à percepção dos efeitos de sentidos ocasionados pela argumentação.

O julgamento de Jean Calas exposto por Voltaire aborda questões políticas, morais, e religiosas. $\mathrm{O}$ discurso dele é elaborado a partir de recursos como comparações, provas intrínsecas e questão de valor. Podemos considerar esses elementos como mecanismos de seletividade na elaboração do discurso persuasivo. Ao evidenciar que os juízes de Toulouse julgaram o caso de Calas de maneira abusiva e violenta, visto que a lei foi manipulada para atender à paixão, ou seja, a intolerância "cega” da opinião pública. Já o conselho do rei julgou de forma imparcial e segundo leis, o orador legitima a importância da tolerância religiosa e da imparcialidade na aplicação das leis.

O julgamento de uma pessoa não deve se pautar em dogmas religiosos e nem na intolerância. Sabe-se que as representações sociais são influenciadas pelas ideias, crenças, valores e ideologias que existem na sociedade e se revelam presentes nos discursos. É possível perceber que Voltaire e Locke construíram seus argumentos acerca da tolerância religiosa no respeito mútuo e que a religião não poderia ser imposta, pois, se assim fosse, não seria verdadeira.

$\mathrm{O}$ amor de Voltaire pela tolerância retoma o discurso dos violentos em uma falsa premissa cristã. Em nome de Deus pessoas foram mortas, povos massacrados, famílias destruídas. Segundo o filósofo, os preceitos religiosos geraram disputas e, essas, por sua vez, resultaram em acontecimentos trágicos. Assim, a religião deveria tornar a vida das pessoas melhor e feliz e, para tanto, era necessário ter compaixão e ser justo.

Locke defendeu a separação entre Estado e igreja e argumentou sobre os limites do poder político. A partir dessa ideia, argumentou que o estado não poderia decretar leis fundamentadas em princípios religiosos. Para Locke, a religião não poderia ser imposta e nem servir de pretexto para perseguir e matar outra pessoa. A tolerância para ele está de acordo com o Evangelho de Jesus Cristo.

Os efeitos argumentativos estão pautados na ideia de valor, que é a base da argumentatividade, e na intenção dos oradores, que é evidenciar que a intolerância religiosa causa a segregação entre as pessoas. Para Voltaire e Locke, a religião deveria fazer parte da convicção de cada pessoa e não poderia ser imposta, ou servir de motivo para oprimir, perseguir, ou ainda justificar as ações desumanas.

Para fundamentar os argumentos em relação à tolerância, os oradores recorrem às citações bíblicas, ao Evangelho, às comparações e palavras como amabilidade, paciência, paz, equidade, amizade, respeito. Os pensadores destacam que para ser "cristão" não basta seguir uma religião e afirmar a fé, mas é necessário praticar ações de caridade e ser mártires e não algozes.

As representações sociais são influenciadas pelas ideias, crenças, valores e ideologias que existem na sociedade e estão presentes nos discursos dos filósofos. 
É possível perceber como Voltaire e Locke utilizam a retórica da tolerância para construírem seus argumentos e persuadir o auditório.

Compreender as estruturas internas retóricas em um discurso, seja ele escrito ou falado, amplia as possibilidades do indivíduo de desenvolver proficiência nas habilidades de leitura, escrita, fala e compreensão da fala, o que o auxilia a utilizar a língua de maneira crítica e consciente, seja para persuadir um auditório ou para compreender a fala ou escrita produzidas.

\section{Referências}

CAMPBELL, K. K.; HUXMAN, S. S.; BURKHOLDER, T. R. Atos de retórica: para pensar, falar e escrever criticamente. São Paulo: Cengage Learning,2015.

FERREIRA, L. A. Leitura e Persuasão. São Paulo: Contexto, 2017.

FIORIN, J. L. Argumentação. São Paulo: Contexto, 2020.

LOCKE, J. Carta sobre a tolerância. Petrópolis, RJ: Vozes, 2019.

MATEUS, S. A introdução à retórica no séc. XXI. Covilhã: Ed. Labcom-ifp. 2018.

REBOUL, O. Introdução à Retórica. São Paulo: Martins Fontes, 2004.

TRINGALI, D. A retórica antiga e as outras retóricas. A retórica como crítica literária. São Paulo: Musa, 2014.

VOLTAIRE. Tratado sobre a tolerância. Tradução Antônio Geraldo Silva. São Paulo: Lafonte, 2017. 